\title{
Impact of Euphorbia helioscopia Extract Administration on Diabetes Induced by Alloxan in Mice
}

\author{
${ }^{1}$ Doha Mohammad Beltagy ${ }^{*}{ }^{2}$ Amira Mohammed Beltagy, \\ ${ }^{1}$ Mohammad Ramadan, ${ }^{3}$ Ehab Tousson and ${ }^{1}$ Batoul Mohamed Izzularab \\ ${ }^{I}$ Department of Chemistry, Biochemistry Division, Faculty of Science, Damanhour University, Egypt \\ ${ }^{2}$ Department of Pharmacognosy, Faculty of Pharmacy, Damanhour University, Egypt \\ ${ }^{3}$ Department of Zoology, Faculty of Science, Tanta University, Egypt
}

\author{
Article history \\ Received: 05-08-2020 \\ Revised: 16-10-2020 \\ Accepted: 19-10-2020 \\ Corresponding Author: \\ Doha M. Beltagy \\ Department of Biochemistry \\ Division, Chemistry, Faculty of \\ Science, Damanhour \\ University, Egypt \\ Tel.: 0201224778799 \\ Fax: 0453293011 \\ Email: dohabel4@yahoo.com
}

\begin{abstract}
Diabetes describes metabolic disorder with hyperglycemia and neurotic changes. This work aimed to evaluate the protective effect of total ethanolic extract of Euphorbia helioscopia grown in Egypt against pancreas and brain injuries in diabetic mice induced by alloxan. This work was carried out on 60 mice divided into four groups. Control Group (G1) included healthy normal mice that did not receive any treatment. $E$. helioscopia extract Group (G2) was administered with the ethanolic extract daily for one week. Alloxan Group (G3) included mice were injected with a single dose of alloxan monohydrate. The treated Group (G4) included mice were injected with alloxan then treated with the extract. The obtained results indicated antidiabetic, neuroprotective, antiapoptotic and antioxidant activities of E. helioscopia in alloxan-induced diabetic mice. The antidiabetic properties of E. helioscopia represented in the reduction in serum glucose levels to $134.13 \pm 1.3$ and the increase in insulin secretion reached to $84.93 \pm 1.16$ if compared to their levels in diabetic mice showed $243.47 \pm 1.73$ and $34.13 \pm 0.99$, respectively. These results were confirmed by histopathological and immunohistological sections in pancreas and brain. In conclusion, ethanolic extract of E. helioscopia can be used as a promising good alternative and complementary therapy for diabetes.
\end{abstract}

Keywords: Euphorbia helioscopia, Diabetes, Alloxan, Apoptosis, Antioxidant

\section{Introduction}

Diabetes Mellitus (DM) describes a group of metabolic disorder in which the person has high blood glucose, either because insulin production is inadequate, or because the body's cells do not respond properly to insulin, or both. According to World Health Organization the diabetic population is likely to increase up to 300 million or more by the year 2025 (Sy et al., 2005). DM can be classified into different types. Among of these is type 1 diabetes which characterized by the destruction of pancreatic cells by an autoimmune attack leading to insulin secretion deficiency. Blood glucose concentration is kept under control by co-ordinate homeostatic physiological reactions in three organs; pancreas, liver and skeletal muscle (Ceretta et al., 2012).

Diabetes causes neurotic changes connected with the Central Nervous System (CNS) that prompt cognizance and moving shortfalls and furthermore raised danger of cerebrum vascular challenges. Various brain variations have been found in diabetes of the creature models enclosing raised hippocampal astrocytic reactivity, vascular adjustment, impaired synaptic plasticity, reduced dendritic complexity and defective neurotransmission (Ogunnowo-Bada et al., 2014). Alloxan in its monohydrate forms is a chemical compound widely utilized as a part of diabetes research to bustle insulin reduction after intra-peritoneal injection (Mamum et al., 2016). It might have aggregated in pancreatic beta cells by the Glucose Transporter (GLUT2) and in the liver where the alloxan is reduced to dialuric acid. Alloxan is an influential pro-oxidant specifically cytotoxic to $B$ cells of the pancreatic islets of Langerhans. Autoxidation of dialuric acid is produced superoxide radicals, hydrogen peroxide and, in a final iron-catalyzed reaction step, hydroxyl radicals. These hydroxyl radicals are eventually responsible for the destruction of the beta cells, which have a particularly low antioxidative defense capacity and the resulting condition of insulin-dependent "alloxan diabetes". 
Alloxan likewise specifically inhibits glucose-induced insulin secretion through its capacity to inhibit the beta cell glucose sensor glucokinase (Lensen, 2008). Alloxan diabetes-induced oxidative stress and causes increase in lipid peroxidation leading to impaired neuronal activity and impairment of oxidative defense system in rat brain, microvascular cerebral diseases, cerebral haemorrhage and brain infarction (Ahmed, 2009). Diabetes or hyperglycemia induced oxidative damage is responsible for the changes occurring in activities of membranebound enzymes of significance in neuronal activity. Despite the fact that is brain consumes $20 \%$ of the oxygen in the body, it has a low content of antioxidants and high content of unsaturated fatty acids and catecholamines (as epinephrine) and that are easily oxidized, making the brain more vulnerable to oxidative damage than any other organs in the body (Schönfeld and Reiser, 2013). All these effects can be appeared after only $72 \mathrm{~h}$ of one-dose alloxan injection (Erukainure et al., 2014).

More than 400 plant species having hypoglycemic effect. However, visitation for new antidiabetic drugs from natural plants is still charming as considering substitution and unharmed than common medications. These plants have antidiabetic impact contain glycosides, alkaloids, terpenoids, flavonoids, carotenoids and so on (Malviya et al., 2010).

Euphorbiaceae is a vast plant family with 300 genera and 5000 species. Euphorbia genus has around 2,000 members making it one of the biggest genera of flowering plants. All govern latex and have unique flower structures. Euphorbia helioscopia Linn is a plant known as sun spurge or wolf's milk. It adjusted to subtropical regions everywhere throughout the world. In Egypt, the plant is basic in Delta and in Upper Egypt it was recorded in many developed yields. The plant consists of diterpens, flavonoids, tannins, polyphenols, glycosides, lipids and volatile oils (Uzair et al., 2009). E. helioscopia has been used as a traditional folk medicine for the treatment of malaria, bacillary dysentery and osteomyelitis. In Chinese medicine, it has been spread used for centuries to treat different disease such as ascites, edema, lung cancer, tuberculosis, scabies, cervical carcinoma and esophageal cancer. It is also believed to have antifungal and antibacterial properties (Wang et al., 2012).

This work aimed to evaluate the potential effect of total ethanolic extract of Euphorbia helioscopia Linn grown in Egypt on both pancreas and brain in diabetic mice induced by alloxan injection.

\section{Materials and Methods}

\section{Collection and Identification of Euphorbia helioscopia Linn}

The whole flowering and fruiting plant of Euphorbia helioscopia Linn was collected from its natural habitats from wheat farms in El-Gharbeya governorate in Egypt in April 2019. The plant was identified by Department of Botany, Faculty of Science, Tanta University, Tanta, Egypt. A voucher specimen was kept in Herbarium of Faculty of Pharmacy, Damanhour University, Damanhour, Egypt under access "No. E.H.3322".

\section{Chemical and Reagents}

Rutin (purity>98\%) and 1,1-Diphenyl-2-Picrylhydrazyl (DPPH) was obtained from Sigma-Aldrich. Ascorbic acid was purchased from Al-Gomhorya Company, Egypt. All solvents and Chemicals used in the study were purchased from Sigma Chemical Co. (St., Louis, USA).

\section{Instruments and Apparatus}

Rotavapor Heidolphvv 20001, Spectrophotometer (Optima SP-300, Japan), Camag, Switzerland UV Lamp, Lyophilyser (Hosokawa, England), Centrifuge (SIGMA3-30 KS, serial no. 150484), Homogenizer (TRYTE, China) and Microplate ELISA reader (MR-96, Clindiag, Belgium) were used in this study.

\section{Preparation of the Total Ethanolic Extract of E. helioscopia}

The dried whole plant $(150$ g) was coarsely pulverized. The air-dried powder was macerated with $70 \%$ alcohol for $24 \mathrm{~h}$ then it was filtered. Extraction was repeated three times till exhaustion. The collected ethanolic extracts were concentrated under reduced pressure in Rotavapor to produce waxy green residue (20 g). For Thin Layer Chromatography (TLC) analysis, 10 $\mathrm{mg}$ of extract was dissolved in $1 \mathrm{~mL}$ ethanol. Ten microliters were deposited on silica gel $\mathrm{F}_{254}$ plate then developed in hexane: Ethyl acetate: Acetic acid (2:2:1) as the solvent system. The plate was visualized under UV then sprayed with $\mathrm{AlCl}_{3}$ and then visualized under UV lamp again. Another plate was sprayed with anisaldehyde/ $\mathrm{H}_{2} \mathrm{SO}_{4}$ and then dried and heated to $120^{\circ} \mathrm{C}$. Ethanolic extract showed 3 spots with $R_{f}$ values: $0.26,0.42$ and 0.88 . Residue was kept in refrigerator in an amber coloured dark stoppered bottle for experiment. $R_{f}$ results indicated three compounds of different polarity. Compound with $R_{f}=0.88$ value is more polar than $R_{f}=0.42$ and the then $R_{f}=0.26$. As the compounds give yellow flourescence under UV on spraying with $\mathrm{AlCl}_{3}$, compounds are flavonoids.

\section{Phytochemical Screening of the Total Ethanolic Extract of E. helioscopia}

Alcoholic extract was subjected to phytochemical screening of various constituents such as sterols, alkaloids, tannins, glycosides, flavonoids and saponins according to Libermann-Burchard reaction, Dragendroff's reaction, ferric chloride solution test, Keller-Kiliani test, Sodium 
hydroxide test, Shinoda test and lead acetate test, respectively (Agbafor and Nwachukwu, 2011).

\section{Determination of Total Flavonoid Content in Alcoholic E. helioscopia Extract.}

Total flavonoid content was determined by adding $4.3 \mathrm{mg}$ of the alcoholic extract and dissolved in $5 \mathrm{~mL}$ of $50 \%$ methanol followed by adding $1 \mathrm{~mL}$ of $5 \% \mathrm{w} / \mathrm{v}$ Sodium nitrite solution and $6 \mathrm{~mL}$ of $10 \% \mathrm{w} / \mathrm{v} \mathrm{AlCl}_{3}$. The sample was incubated for an hour at room temperature. Then absorbance was determined using spectrophotometer at $\lambda \max =415 \mathrm{~nm}$. The sample was prepared in triplicate and the mean value was calculated. Standard solutions of rutin were prepared and the calibration line was construed. Based on the measured absorbance, the concentration of flavonoids was read $(\mathrm{mg} / \mathrm{mL})$ on the calibration line; then, the content of flavonoids in the extract was expressed in terms of rutin equivalent ( $\mathrm{mg}$ of RU/g of extract) (Quettier-Deleu et al., 2000).

\section{Determination of Total Antioxidant Properties of Alcoholic E. helioscopia Extract.}

The antioxidant activities of the ethanolic extract of E. helioscopia was assessed using 1,1-Diphenyl-2Picrylhydrazyl (DPPH) with ascorbic acid as standard. $50 \mathrm{mg}$ of the extract was dissolved in $1 \mathrm{~mL}$ ethanol. Then, $250 \mu \mathrm{L}$ of the dissolved sample was added to 1 $\mathrm{mL}$ DPPH/ethanol solution $(6 \mathrm{mg} / 50 \mathrm{~mL})$ and the total volume was adjusted to $3 \mathrm{~mL}$ with ethanol. After vortexing, the mixture was incubated for $30 \mathrm{~min}$ in dark at room temperature. Absorbance was measured using at $517 \mathrm{~nm}$. Serial dilutions $(5-50 \mathrm{mg} / \mathrm{mL})$ of the extract were measured by the same assay to obtain $\mathrm{IC}_{50}$ (the amount of the extract that gives half-maximal scavenging response) (Bayati and Yazdanparast, 2011).

\section{Animal Groups}

This study carried out on 60 albino mice weight territory (25-30 g). They were obtained from the animal breeding colony of Zoology Department, Faculty of Science, Tanta University, Egypt. All animals were housed in plastic cages; animal cages were kept clean, the animals were acclimatized for a week before the onset of experiments under standard laboratory conditions (the temperature in the animal room was maintained at $23 \pm 2^{\circ} \mathrm{C}$ with a relative humidity of $55 \pm 5 \%$ and light was on a12:12 h light/dark cycle). Animal were maintained on a standard diet, Egyptian Company of Oils and Soap, Kafr-El-Zayat; Egypt) and water ad libitum. Animal maintenance and treatments were conducted in accordance with Faculty of Science, Tanta University guide for animals, as approved by the Institutional Animal Care and Use Committee (IACUCSCI-TU-0074). The mice were randomly divided into four groups (fifteen for each). The first Group (G1, control) included mice were injected with only saline and served as the control group, the second group (G2, E. helioscopia extract) were administered with only the ethanolic extract of Euphorbia helioscopia Linn daily by a dose of $400 \mathrm{mg} / \mathrm{Kg}$ for one week (Devi and Kumar, 2017); the third Group (G3, alloxan) included mice were injected with single intraperitoneal dose $(200 \mathrm{mg} / \mathrm{kg})$ of freshly prepared alloxan monohydrate (Research-lab fine chem. Industries) according to (Bukhari et al., 2015) and the fourth Group (G4, treated mice) was treated with the ethanolic extract of E. helioscopia $(400 \mathrm{mg} / \mathrm{Kg})$ once daily for one week after injection of alloxan monohydrate. Mice in all groups showed zero mortality till the end of the experiment period.

\section{Samples Collection}

Blood samples were gathered in the plain tube after anesthetized mice by utilizing diethyl ether. The blood was gathered from the orbital sinus and the specimens were centrifuged at $110 \mathrm{~g}$ for $15 \mathrm{~min}$ to obtain serum. The pancreas and brain tissues were instantly removed and partitioned into two parts. Each part is washed with ice-cold saline solution. The first part was fixed in $10 \%$ formalin to be used in histopathological and immunohis tochemical examination, while, the other part was stored at $-80^{\circ} \mathrm{C}$ until used. Serum samples were used for determine the glucose and insulin concentration. Stored tissues of pancreas and brain were utilized for determination of antioxidant parameters, 8-hydroxydehydrogenase and 5-nucleotidase enzymes. Neurotransmitters were measured in the brain tissue.

\section{Homogenate Preparation}

Both pancreas and brain tissues were set up concurring for determination of antioxidant parameters. To evacuate any red blood cells and clots from tissues, they were washed with Phosphate Buffered Saline (PBS) $\mathrm{pH} 7.4$ containing $0.16 \mathrm{mg} / \mathrm{mL}$ heparin. At that point the tissues were homogenized in $5-10 \mathrm{~mL}$ cold buffer (around $50 \mathrm{mM}$ potassium phosphate $\mathrm{pH} 7.5,1 \mathrm{mM}$ EDTA) per gram tissue utilizing tissue homogenizer. At that point the samples were centrifuged at $1770 \mathrm{~g}$ for 15 $\min$ at $4^{\circ} \mathrm{C}$. The supernatant were evacuated for examine and put away on ice.

\section{Determination of Diabetes Markers}

The enzymatic colorimetric test for glucose was assessed by GOD-PAP method (Rohlfing et al., 2002). Insulin was assayed in the Medical Service Unit of the National Research Center (Dokky-Giza, Egypt) by ELISA kits (Byersdorfer et al., 2005). 
Determination of 8-Hydroxy Dehydrogenase and 5'-Nucleotidase in Pancreas Tissue

8-hydroxy dehydrogenase Enzyme (EC 1.1.1.51) was assessed using ELISA kit of FineTest, Catalogue No ER1487, China. The color change can be measured at a wavelength of $450 \mathrm{~nm}$. 5'-Nucleotidase (EC 3.1.3.5) was assessed by using DIAZYME kit, catalogue No. DZ123A-K, USA. The 5'-NT assay was based on the enzymatic hydrolysis of $5^{\prime}$-monophosphate (5'-IMP) to form inosine which is converted to hydroxanthine by Purine Nucleoside Phosphorylase (PNP). Hydroxanthine is then converted to uric acid and hydrogen peroxide $\left(\mathrm{H}_{2} \mathrm{O}_{2}\right)$ by Xanthine Oxidase (XOD). $\mathrm{H}_{2} \mathrm{O}_{2}$ is further reacted with N-Ethyl-N-(2-Hydroxy-3-Sulfupropyl)-3methylaniline (EHSPT) and 4-Aminoantipyrine (4AA) in the Presence Of Peroxidase (POD) to generate quinone dye which is monitored in a kinetic manner (Bertrand and Buret, 1982).

\section{Determination of Antioxidant Parameters in Pancreas and Brain Tissues}

Detection of reduced glutathione was carried out by the colorimetric technique by using the kit of BioDiagnositic, Egypt, CAT. No GR2511 depending on the oxidation of GSH by 5,5'-Dithiobis-2-Nitrobenzoic acid [DTNB] and the resultant yellow colored complex is measured at $412 \mathrm{~nm}$ (Beutler, 1963).

The detection of lipid peroxide (Malondialdehyde) was completed by colorimetric methods. Thiobarbituricacid reactive product was produced by reaction of Thiobarbituric Acid (TBA) with Malondialdehyde (MDA) in acidic medium at temperature of $95^{\circ} \mathrm{C}$ for $30 \mathrm{~min}$. The resultant pink output can be estimated at $534 \mathrm{~nm}$ (Ohkawa et al., 1979).

Super Oxides Dismutase (SOD) (EC 1.15.1.1) estimation was carried out depending on the colorimetric technique using the BioDiagnositickit, Egypt, CAT. No \# SD2521. This experiment relies on the capacity of enzyme to inhibit the phenazinemethosulphate mediated reduction of nitro-blue tetrazolin dye. Absorbance detected at $560 \mathrm{~nm}$ more than $5 \mathrm{~min}$ for both control and sample at $25^{\circ} \mathrm{C}$ (Nishikimi, 1975).

Catalase Enzyme (EC 1.11.1.6) was evaluated by colorimetric method according to BioDiagnositic kit, Egypt, CAT. No \# SD2517. The reaction relied upon the response between the catalase and known amount of $\mathrm{H}_{2} \mathrm{O}_{2}$ to produce a Quinoneimine dye which can be measured at $510 \mathrm{~nm}$ (Saggu et al., 2014).

\section{Determination of Neurotransmitters in Brain Tissue}

Glutamate concentration was quantitatively measured according to glutamate ELISA Kit Catalog Number KA1909, ABNOVA. Epinephrine concentration was estimated using Mouse Epinephrine/Adrenaline (EPI) ELISA Kit, Cat. No.\# MBS011202, MyBioSource.
Serotonin was assessed using serotonin ELISA Kit, Cat. No.\# ab133053. Melatonine concentration was evaluated using ELISA Kit (Competitive EIA), Catalog No.\# LSF25779, life spam biosciences, INC.

\section{The Histopathology Staining}

Brains and pancreas were washed in saline solutions, fixed in $10 \%$ neutral buffered formalin, dehydrated, cleared, embedded in paraffin and sectioning. Paraffin sections were stained with Ehrlich's haematoxylin stain and counterstained with eosin as a routine method (Tousson, 2016).

\section{P53 Expression in Pancreas}

Expression of P53-ir (P53 immunoreactivity) in pancreas sections was detected using the Avidin Biotin Complex method (ABC) (Tousson et al., 2012). Sections were incubated with anti-rabbit P53 monoclonal antibody (Dako, 1:80) for two hours at room temperature. The criterion for a positive reactions $(+\mathrm{Ve})$ confirming the presence of P53 as a dark brownish and intra cytoplasmic precipitate. For the negative control, the 1ry antibody was omitted to guard against any false + Ve results which develop from a non specific reactions.

\section{Glial Fibrillary Acidic Protein (GFAP) Immunohistochemistry}

Expression of GFAB immunoreactivity (GFAB-ir) in coronal sections of cerebral cortex was detected using the avidin biotin peroxidase complex method, according to (Bondan et al., 2013). Sections were incubated with Polyclonal rabbit anti-GFAP immunoglobulin (Z0334, Dako), at a dilution of 1:1000, was used as the primary antibody, for $16 \mathrm{~h}$ at room temperature.

\section{Statistical Analysis}

The statistical analysis of data was carried out by using Graph Pad instat, Version 6.01 (GraphPad Software Inc., San Diego, California USA). The obtained data were expressed as mean \pm Standard Deviation (SD). Significant differences between the means were determined by one-way ANOVA test. P-value less than 0.05 were considered as statistically significant. Graphs were plotted using Microsoft excel 2010.

\section{Results}

Phytochemical Screening, Total Flavonoidal Content and Total Antioxidant Activity of $E$. helioscopia Extract

Phytochemical screening of the ethanolic extract of E. helioscopia confirmed the presence of carbohydrates, flavonoids, catechol tannin and sterols. Alkaloids are present with minor concentration in the alcoholic extract. 
E. helioscopia extract showed relatively high total flavonoidal content of $215.68 \mathrm{mg}$ of $(\mathrm{mg}$ of $\mathrm{RU} / \mathrm{g}$ of extract).

The results obtained by ethanolic E. helioscopia extract showed antioxidant activities were very close to that obtained by the ascorbic acid (the reference compound) representing $\mathrm{IC}_{50}$ of 7.88 and $3.41 \mathrm{mg} / \mathrm{mL}$ for $E$. helioscopia extract and ascorbic acid, respectively Table 1.

\section{Assessment of Diabetes Biomarkers}

The results showed that there were no significant differences between $\mathrm{G} 1$ and $\mathrm{G} 2$ (control and $E$. helioscopia groups) in glucose concentration and insulin levels and in 8-HSDG and 5'-Nucleotidase activities. While there was a significant increase in glucose concentration in G3 (alloxan) compared with G1 and G4 (treated mice). While, there were significant decrease in insulin concentration and 8HSDG and 5'-Nucleotidase activities in G3 in comparison with normal values. These values were returned to be increased after treatment to reach to nearly normal values in G4 Table 2.

\section{Determination of Neurotransmitters}

The data showed that there was no difference between G1 and G2 (control and E. helioscopia groups) in almost all the neurotransmitter determined. As well there were significant decreases in all measured neurotransmitters in G3 (alloxan) compared with G1. Also the results confirmed that there were significant increases in G4 (treated mice) compared with G3 Table 3.

\section{Determination of Antioxidant}

There were significant decreases in GSH concentration in both pancreas and brain tissue in G3 (alloxan) compared with G1 (control). There were significant increases in GSH level in both pancreas and brain tissue in G4 compared with G3. The data confirmed that all MDA, SOD and CAT level in both pancreas and brain tissues significantly increased in G3 compared with G1. MDA, SOD and CAT levels decreased in both pancreas and brain tissues in G4 (treated mice) compared with G3 Fig. 1.

\section{Histopathological Findings in the Brain}

Coronal sections in cerebral cortex of control (G1) and in treated mice with E. helioscopia extract (G2) revealed a normal neuronal structure of the neurons and nerve fibers Fig. 2A and 2B. Cerebral cortex sections in diabetic mice (G3) revealed various histopathological changes, as the presence of a moderate number of damages and degenerating neurons with moderate neuronal atrophy Fig. 2C. On the other hand; cerebral cortex sections in treated diabetic mice with E. helioscopia extract (G4) group revealed a good degree of improvement with only mild degenerating neurons Fig. 2D.

\section{GFAB Immunohistochemical Changes in Cerebral Cortex}

The detection and distribution in GFAB immunoreactivity (GFAB-ir) in brain sections in the different groups under study were revealed in Fig. 4a-4d. Cerebral cortex section in control $(\mathrm{G} 1)$ and in treated mice with E. helioscopia extract (G2) groups revealed mild positive reaction for GFAB-ir in neurons Fig. 3A and $3 \mathrm{~B}$. In contrast; strong positive reactions for GFAB-ir in the cerebral cortex sections in treated diabetic mice Fig. 3C. Brain cortex sections in treated diabetic mice with E. helioscopiaextract (G4) revealed mild to moderate positive reactions for GFAB-ir in neurons Fig. 3D.

Table 1: Analysis of phytochemical screening, flavonoids and antioxidant properties of the ethanolic E. helioscopia extract

\begin{tabular}{llc}
\hline Phytochemical screening & $\begin{array}{l}\text { Carbohydrates, flavonoids, catechol tannin, } \\
\text { sterols with minor alkaloids content }\end{array}$ & $215.68 \pm 0.003$ \\
\hline $\begin{array}{l}\text { Falvonoidal content [mg of (mg of RU/g of extract)] } \\
\text { Antioxidant properties }\end{array}$ & & $\mathrm{IC} 50(\mathrm{mg} / \mathrm{mL})$ \\
Radical scavenging activities percentage (\%) & $72.67 \pm 2.36$ & 7.88 \\
E. helioscopia extract & $88.59 \pm 1.98$ & 3.41 \\
Ascorbic acid (Reference) & & \\
\hline
\end{tabular}

Table 2: Assessment of some diabetes biomarkers

\begin{tabular}{lllll}
\hline Parameter & G1 & G2 & G3 & G4 \\
\hline Glucose $(\mathrm{mg} / \mathrm{dl})$ & $111.8 \pm 1.61$ & $111.93 \pm 1.39$ & $243.47 \pm 1.73^{*}$ & $134.13 \pm 1.3^{*, * *}$ \\
Insulin $(\mathrm{Pmol} / \mathrm{mL})$ & $165.27 \pm 1.49$ & $165.00 \pm 1.20$ & $34.13 \pm 0.99^{*}$ & $84.93 \pm 1.16^{*}, * *$ \\
8-HSDG $(\mathrm{ng} / 100 \mathrm{mg})$ & $246.00 \pm 2.67$ & $244.20 \pm 1.88$ & $17.80 \pm 0.34^{*}$ & $205.00 \pm 0.89^{*, * *}$ \\
5'-Nucleotidase $(\mathrm{U} / \mathrm{mL})$ & $148.00 \pm 1.45$ & $146.00 \pm 1.50$ & $9.00 \pm 0.20^{*}$ & $114.00 \pm 1.12^{*}, * *$ \\
\hline P value $(\mathrm{P}<0.05)$ is significant; $*$ : Significant compared with G1, **. Significant compared with G3 &
\end{tabular}


Doha Mohammad Beltagy et al./ OnLine Journal of Biological Sciences 2020, 20 (3): 144.156 DOI: 10.3844/ojbsci.2020.144.156

Table 3: Neurotransmitters levels in brain homogenate of different groups

\begin{tabular}{lllll}
\hline Parameter & G1 & G2 & G3 & G4 \\
\hline Glutamate $(\mu \mathrm{g} / \mathrm{mg})$ & $3.173 \pm 0.096$ & $3.147 \pm 0.092$ & $1.24 \pm 0.063^{*}$ & $2.08 \pm 0.086^{*}, * *$ \\
Epinephrine $(\mathrm{Pg} / \mathrm{mg})$ & $219.2 \pm 2.7$ & $219.2 \pm 3.33$ & $66.73 \pm 1.71^{*}$ & $111.73 \pm 1.58^{*}, * *$ \\
Serotonin $(\mathrm{ng} / \mathrm{mg})$ & $213.87 \pm 1.88$ & $213.6 \pm 2.32$ & $75.2 \pm 1.37^{*}$ & $188.67 \pm 1.68^{*, * *}$ \\
Melatonin $(\mathrm{Pg} / \mathrm{mg})$ & $14.16 \pm 0.112$ & $14.14 \pm 0.13$ & $6.373 \pm 0.128^{*}$ & $11.233 \pm 0.154^{*, * *}$ \\
\hline
\end{tabular}

$\mathrm{P}$ value $(\mathrm{P} \leq 0.05)$ is significant; *: Significant compared with $\mathrm{G} 1$, **: Significant compared with G3

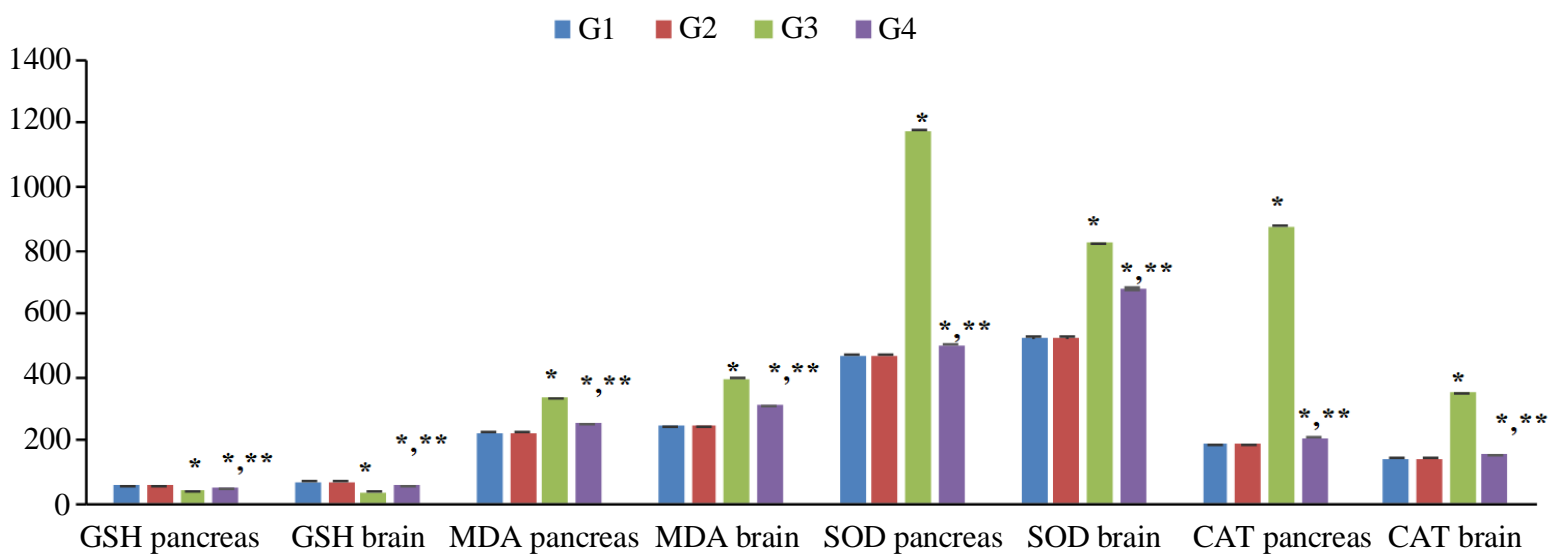

Fig. 1: Antioxidants levels in both pancreas and brain tissues. $P$ value $(P \leq 0.05)$ is significant; *: Significant compared with $\mathrm{G} 1$, **: Significant compared with G3
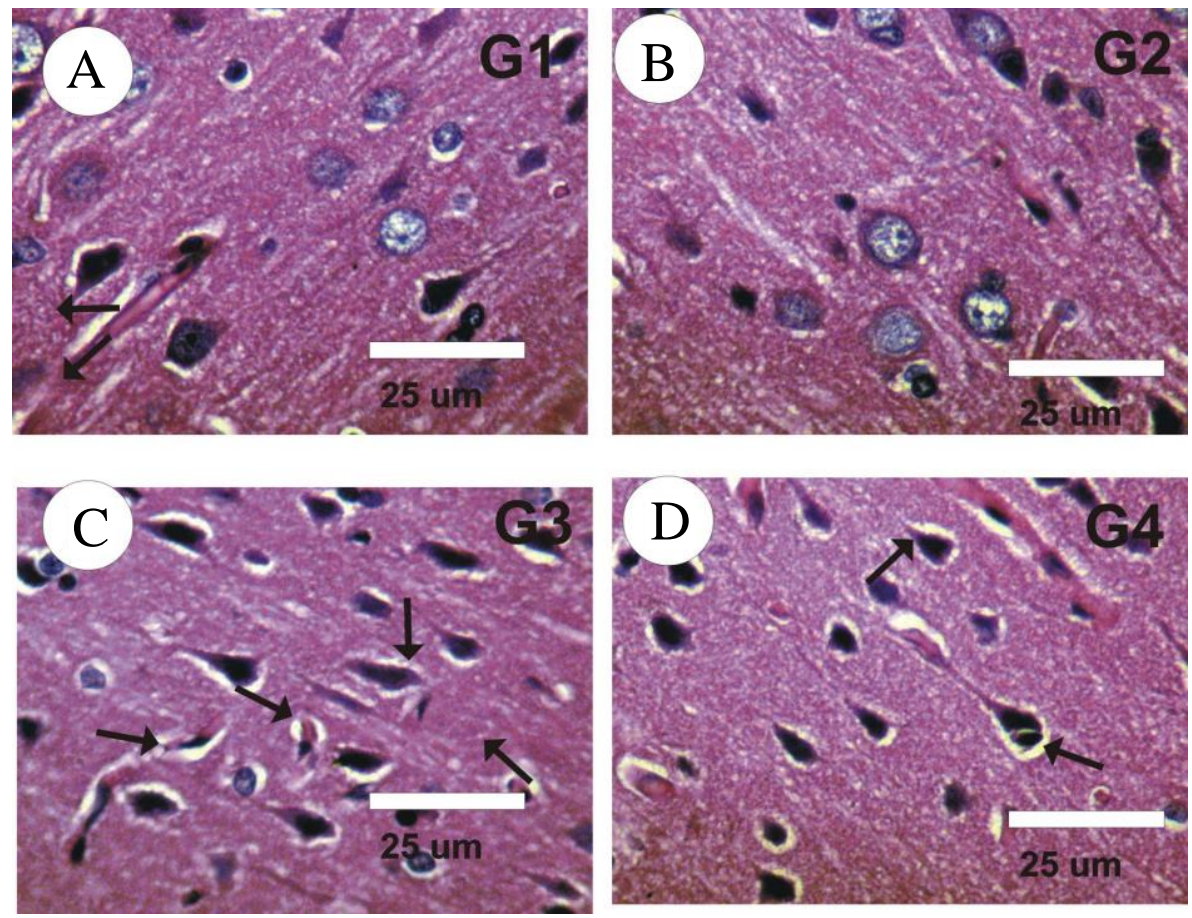

Fig. 2: Photomicrographs of mice brain cortex sections in the different experimental groups stained with Haematoxylin and Eosin. $(\mathrm{A} \& \mathrm{~B})$ Cerebral cortex sections in control $(\mathrm{G} 1)$ and treated mice with E. helioscopia extract $(\mathrm{G} 2)$ revealed normal neuronal structure of the neurons and nerve fibers. (C Cerebral cortex sections in diabetic mice revealed the presence of a large number of damages neurons, atrophied and degenerating neurons (Black arrows). (D) Cerebral cortex sections in diabetic mice treated with E. helioscopia extract (G4) revealed mild degenerating neurons (Black arrow) 

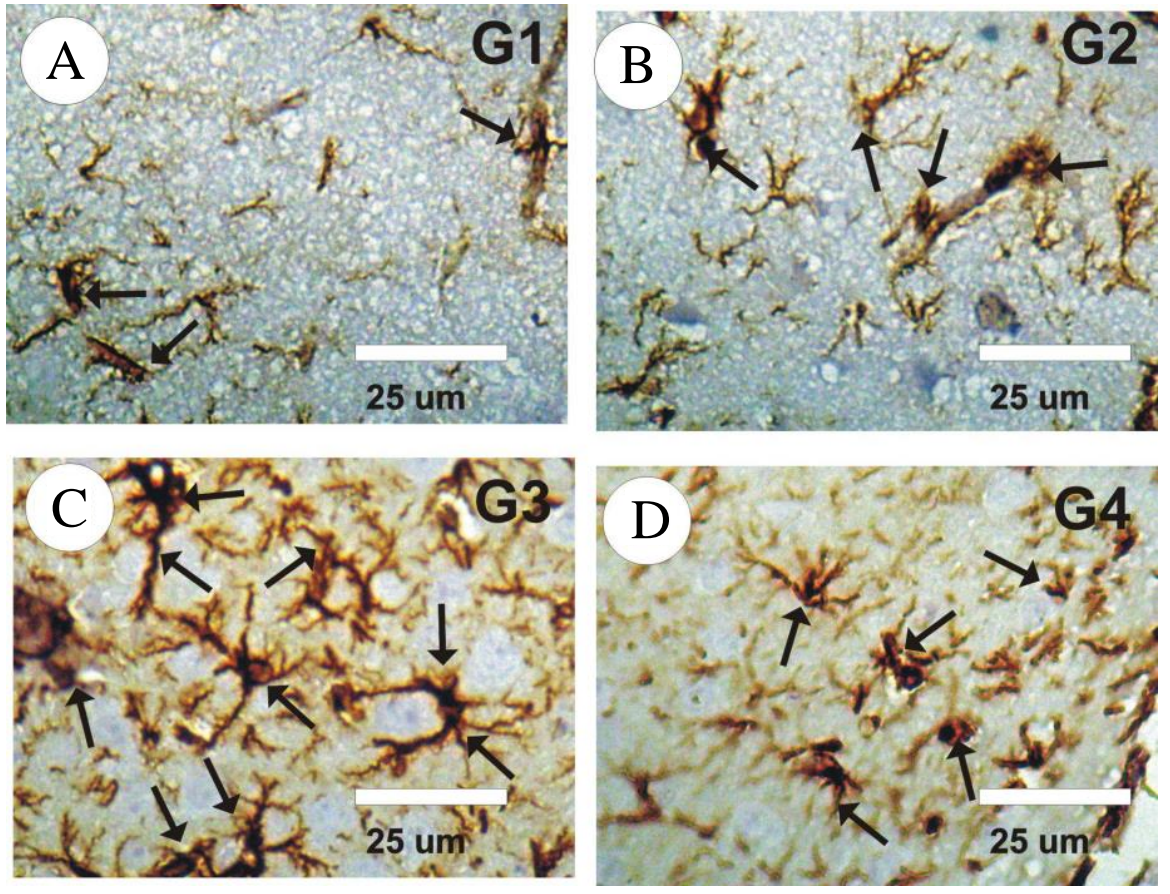

Fig. 3: Photomicrographs of mice cerebral cortex sections in the different experimental groups stained with GFAB-ir. (A\&B) Mild positive reactions for GFAB-ir in the cortex of control (G1) and treated mice with E. helioscopia extract (G2). (3C) Strong positive reactions (arrows) for GFAB-ir in the cortex sections in diabetic mice (G3).(3D) Mild to moderate positive (arrows) expressions for GFAB-ir was observed in the cerebral cortex sections in diabetic mice treated with E. helioscopia extract (G4)
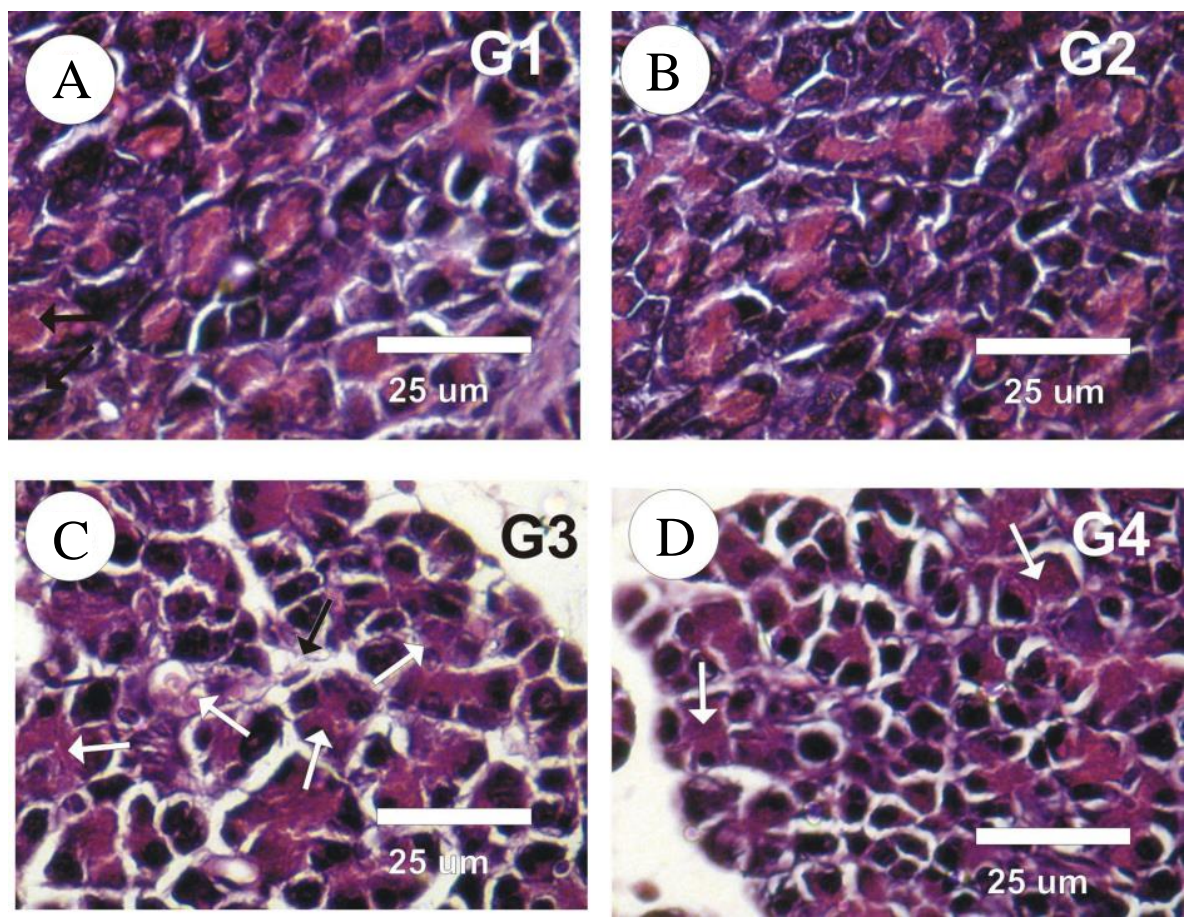

Fig. 4: Photomicrographs of mice pancreas sections in the different experimental groups stained with Haematoxylin \& Eosin. (4A\&4B) Pancreas sections in control (G1) and treated mice with E. helioscopia extract (G2) revealed normal acini structure in exocrine part. (4C) Pancreas sections in diabetic mice revealed moderate acinar damage (White arrows) represented by cytoplasmic vacuolation (Black arrows), degeneration, swollen and cell atrophy. (4D) Pancreas sections in diabetic mice treated with $E$. helioscopia extract (G4) revealed a few degeneration and mild moderate damage acinar (White arrows) 

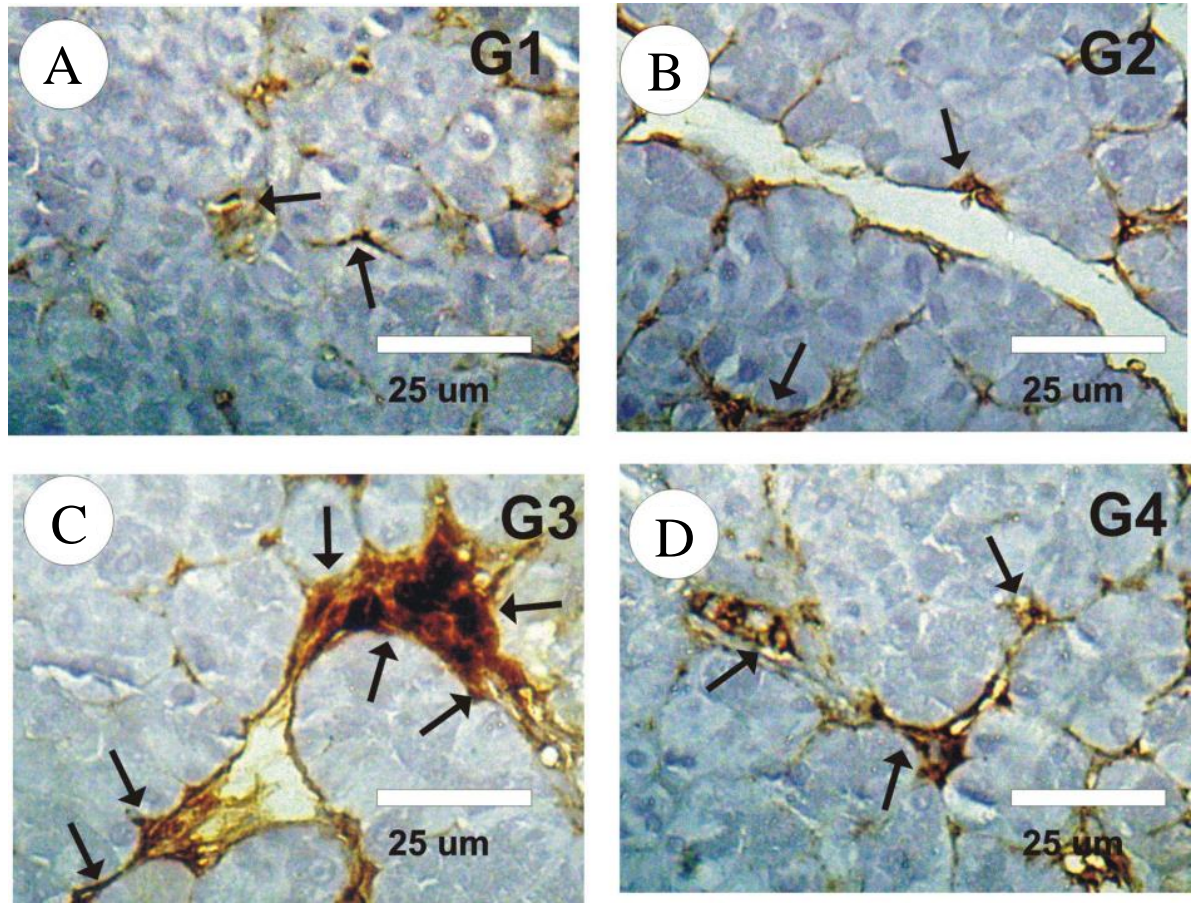

Fig. 5: Photomicrographs of mice pancreas sections in the different experimental groups stained with P53-ir. (A\&B) Mild positive reactions for P53-ir in the pancreas of control (G1) and treated mice with E. helioscopia extract (G2). (C) Strong positive reactions (arrows) for P53-ir in the pancreas sections in diabetic mice (G3). (D) Mild to moderate positive (arrows) expressions for P53-irwas observed in the pancreas sections in diabetic mice treated with E. helioscopia extract (G4)

\section{Histopathological Findings in the Pancreas}

Microscopic investigation of pancreas sections of control (G1) and treated mice with E. helioscopia extract (G2) showed normal appearance of islets of Langerhans. The islets appeared lightly stained than the surrounding acinar cells. The acinar cells are formed of pyramidal cells with basal nuclei and apical acidophilic cytoplasm Fig. 4A and 4B. In contrast, pancreas sections in diabetic mice (G3) showed shrinkage of normal architecture of the pancreatic islets with very scanty inflammatory cell infiltration, mild eosinophilic deposits, decrease in the number and size of islet of Langerhans as compared to control. Also; most of acinar cells in pancreas sections in diabetic mice revealed acinar damage represented by cytoplasmic vacuolation, degeneration, swollen and cell atrophy Fig. 4C. On the other hand; pancreas sections in treated diabetic mice with E. helioscopia extract (G4) group revealed a moderate degree of improvement with only mild atrophy and vacuolation were observed in the acinar cells Fig. 4D.

\section{P53 Immunohistochemical Changes in Pancreas}

Detection and distribution in P53 immunoreactivity (P53-ir) in pancreas sections in the different groups under study were revealed in Fig. 5. Pancreas section in control (G1) and in treated mice with E. helioscopia extract (G2) groups revealed mild positive reaction for P53-ir in acini and intralobular ducts Fig. 5A and 5B. In contrast; strong positive reactions for $\mathrm{P} 53$-ir in the pancreas sections in treated diabetic mice (Fig. 5C). Pancreas sections in treated diabetic mice with E. helioscopia extract (G4) revealed mild to moderate positive reactions for P53irinacini and intralobular ducts Fig. 5D.

\section{Discussion}

Diabetes mellitus is the metabolic disorder with chronic hyperglycemia because of defective insulin secretion, impedance to insulin action or both (Ibrahim, 2017). Many plants have been found to contain substances like glycosides, alkaloids, terpenoids, flavonoids that are as often as possible involved as having antidiabetic impacts. The exploration for exchange cures from the plant kingdom for diabetes are proceed (Petchi et al., 2013). The purpose of this work was to discover a new antidiabetic drug of plant origin.

Euphorbia helioscopia is well known in folk medicine in many countries in treatment of different diseases. The latest therapeutic revelation for this plant was its insulin secretagogue activity. Many in vitro studies on the ethanolic extract of E. helioscopia, collected from Islamabad and the Murree region of Pakistan, were carried out to look into the effect of these medicinal plants on insulin secretion from INS-1 cells. 
INS-1 cells secrete insulin without peracrine influence. It gave excellent antihyperglycaemic activity (Abou-El-Hamd et al., 2012) but there are no any in vivo studies confirmed that. The ethanolic extract of Euphorbia helioscopia was approved to be safe and showed no mutagenic and genotoxic potentials at probably high concentrations (Saleem et al., 2015). This encourages us to investigate antidiabetic, antioxidant and antiapoptotic effects of this plant naturally grown in Egypt. In this study, ethanolic extract of Euphorbia helioscopia were used in reducing of the toxic effect of alloxan on both pancreas and brain.

Plants contain flavonoids, terpenoids, alkaloids and glycosides have antioxidant activities expected to possess antidiabetic effect. Flavonoids are the naturally occurring secondary metabolites in plants shown to be highly effective free radicals scavengers (Kalaivani and Mathew, 2010). From our results, the total flavonoids in E. helioscopia extract showed high content by about $215.68 \mathrm{mg}$ of RU/g of extract. E. helioscopia extract also showed excellent radical scavenging activities $(72.67 \%)$ which is close to that obtained by ascorbic acid ( $88.59 \%)$ with relatively low $\mathrm{IC}_{50}(7.88 \mathrm{mg} / \mathrm{mL})$. Flavonoids in the plant recover the harmed pancreatic $\beta$-cells and the polyphenolic mixes introduce in the plants hinder glucose transport by repressing Sodium Glucose co-Transporter-1 (S-GLUT-1) in digestive tract. Antidiabetic effect of the ethanolic extract of the whole plant might be due to presence of flavonoids, polyphenolic compounds and saponin (Petchi et al., 2013). Phytochemical analysis of the extract showed that the extract contains caffeic acid, lignin, malic acid, n-hexadecanoic acid and carvacrol which has protective effects on liver and possess antioxidant activity (Beltagy, 2019).

Alloxan is used in experimental design as a diabetogenic agent which can be rapidly up-taken by pancreatic $\beta$-cells (Lensen, 2008). So, it can cause specific necrosis of the pancreatic beta cells (Peschke et al., 2000). It evokes a sudden rise in insulin secretion in the presence or absence of glucose for short period then complete suppression of the insulin-secreting $\beta$-cells occurs. Toxicity of alloxan is caused by its reduction into dialuric acid by glutathione to generates free radicals that damages the beta cells (Gwarzo et al., 2010).

Serum glucose concentrations in mice that administered with only alloxan for once (G3) showed highly significant elevation reached to about 2.17 fold increase in comparison with normal control mice (G1). After treatment with the ethanolic extract (G4) this blood glucose concentrations decreased to reach to about 1.2 fold increase in comparison with its normal ranges. On the other hand, insulin concentrations showed highly significant decrease reached to about one-fifth of its normal ranges in alloxan injected mice and after the treatment with the extract, insulin concentrations showed gradually regression to reach to one-half of the normal ranges. These results were in line with a lot of previous studies that reported elevation in glucose concentration in combination with significant decrease in insulin secretion in alloxan administered rats (Victor et al., 2017).

Hydroxysteroid Dehydrogenase (HSD) catalyzes the dehydrogenation process and it is classified according to the number of the carbon acting on. The significance of HSD in glucose homeostasis is proposed by the resistance of it in mice to hyperglycemia upon stress or obesity, due to attenuated gluconeogenic reactions. 5' Nucleotidase ( $5^{\prime} \mathrm{NTD}$ ) catalyzes the release of inorganic phosphate from nucleoside-5-phosphates. 5'NTD levels significantly changed in diabetes (Al-Abachi et al., 2012; Sourianarayanane, 2018). From the obtained results, there was significant decrease in HSD and 5 NTD activities in diabetic mice in comparison with normal mice reached to 0.07 and 0.06 folds decrease, respectively. These enzymes activities are increased by the treatment with the ethanolic extract of E. helioscopia to reach to about 0.83 and 0.77 of its normal values. These findings were previously documented by previous studies (Morton et al., 2001).

The formation of reactive oxygen species is preceded by alloxan reduction by GSH inside $\beta$-cells. Since alloxan exhibits a high affinity to the SH-containing cellular compounds (Sakurai and Ogiso, 1991). Superoxide dismutase, catalase and non-enzymatic scavengers of hydroxyl radicals were found to protect against alloxan toxicity (Lensen, 2008).

The results showed that the concentration of GSH was significantly decreased in both pancreas and brain tissues of mice injected with alloxan (G3) by 0.73 and 0.55 folds, respectively. These results indicated that both pancreas and brain tissue were under oxidative stress due to induction of alloxan injection. After treatment with $E$. helioscopia extract, the results showed significant increase of GSH concentration in G4 in both pancreas and brain tissues compared with G3. The results suggested that E. helioscopia extract played important roles in the recovery of the oxidative stress caused by alloxan in both pancreas and brain tissue depending on the increase of GSH level (reduced form) ability to bind with reactive oxygen species (Sahu et al., 2015).

The results showed significant increases in MDA concentrations in pancreas and brain tissues in diabetic mice (G3) compared with normal control mice (G1). These increases reached to about 1.5 and 1.6 folds in pancreas and brain tissues of G3, respectively if compared with G1. MDA concentrations in mice treated with E. helioscopia extract (G4) decreased to nearly normal values. It can be explained by that MDA is resulted from the reaction of reactive oxygen species with unsaturated fatty acids, so the high elevation levels 
of MDA confirm oxidative stress due to the induction with alloxan (Bakırel et al., 2008). It clarifies the ability of Euphorbia helioscopia extract to relief toxic effects on both pancreas and brain tissue (Reddy and Uppala, 2014).

SOD and CAT enzymes protect cells from antioxidant stress. They produce vital parts of cellular antioxidant defense mechanism (Tang et al., 2010). From the obtained results, there were significant increases in SOD activities in both pancreas and brain tissues in diabeteic mice (G3) compared with normal mice (GI). The activities of SOD increased by about 2.5 and 1.6 folds in G3 compared with G1 in pancreas and brain tissues, respectively. After treatment with $E$. helioscopia extract, SOD activities decreased by about 0.42 and 0.82 in G4 compared with G3. By a similar way, the activities of CAT elevated in G3 to about 4.6 and 2.5 folds compared with G1 in both pancreas and brain tissues, respectively. Then it decreased after treatment with E. helioscopia extract by about 0.24 and 0.44 folds in G4 compared with G3. The high activities of both CAT and SOD enzymes in diabetic mice (G3) suggested that the pancreas and brain tissue exposed to highly oxidative stress and the decreased activities recorded for E. helioscopia extract treated mice confirmed that Euphorbia helioscopia play an important role in protection of the cells from the oxidative stress. These results are in line with previous studies (Pandya et al., 2017).

Alloxan has toxic effects causing damages in brain tissues. The levels of all neurotransmitters included in this study (glutamate, epinephrine, serotonin and melatonin) significantly decreased in diabetic mice (G3) if compared with normal mice (G1). Glutamate is the most significant free amino acid in the brain and is at the intersection between different metabolic pathways. It stimulates cells to excitotoxicity (Zhou and Danbolt, 2014). Melatonin and serotonin are neurohormones emitted from pineal gland. They have excellent antioxidant properties and are able to remove oxygenous and nitrogenous free radicals (Ibrahim, 2017). Epinehrine has a diabetogenic impact by its capacity to interfere with each of the components of the glucoregulatory action (Sherwin and Sacca, 1984).

From the obtained data, glutamate, epinephrine, serotonin and melatonin concentrations decreased in brain tissues of diabetic mice (G3) by about $0.4,0.3$, 0.35 and 0.44 folds, respectively if compared with normal mice (G1). While after treatment with $E$. helioscopia extract there were significant improvements for all these neurotransmitters. The results showed that there were significant increases of glutamate, epinephrine, serotonin and melatonin concentrations in G4 (treated mice) compared with G3 (alloxan group). The concentrations increased after treatment with $E$. helioscopia extract (G4) by about 1.6, 1.7, 2.5 and 1.7 for glutamate, epinephrine, serotonin and melatonin, respectively if compared with diabetic mice (G3). Many previous studies agreed with these results (Arora and Deshmukh, 2017; Ibrahim, 2017). The fundamental mechanism underlying hyperglycaemia in diabetes mellitus involves decreased utilization of glucose by the brain. The failure in the maintenance of normal energy metabolism during diabetes (reflected by alterations occurring in adenine nucleotide and the ATPases) might affect glucose homeostasis leading to gross cerebral dysfunction during diabetes (Ahmed and Zahra, 2011). This can be explained by the suggestion based on that hyperglycemia thusly causes up to a fourfold increment in neuronal glucose. This evaluation leads to increase in the intracellular glucose metabolism which leads to neural injury (Ceretta et al., 2012).

The immunohistopathological of P53 in pancreas tissue results were in the line with the previously findings indicated that p53 plays a significant role in the development of many metabolic disorders as diabetes (Kung and Murphy, 2016). By the same manner the type III intermediate filament protein, Glial Fibrillary Acidic protein (GFAB) in the brain tissue were highly expressed in diabetic mice brains by numerous cell types of the Central Nervous System (CNS), including astrocytes. These findings are previously documented (Coleman et al., 2004).

\section{Conclusion}

This study indicated the antidiabetic, neuroprotective, antiapoptotic and antioxidant activities of the ethanolic extract of Euphorbia helioscopia which is naturally grown in Egypt on wheat and pea in alloxan-induced diabetic mice. This study suggested that E. helioscopia may be promoted among the masses as a safe alternative and complementary therapy for diabetes. Further clinical studies may be needed to clarify the toxicological and pharmacological aspects of E. helioscopia extract.

\section{Acknowledgement}

There is no financial support received for this research.

\section{Author's Contributions}

\section{Doha Mohammad Beltagy, Batoul Mohamed Izzularab and Amira Mohammed Beltagy:} Participated in all experiments, coordinated the dataanalysis and contributed to the writing of the manuscript.

Mohammad Ramadan: Participated in the mice work.

Ehab Tousson: Participated in the histopathological and immunohistochemical staining and analysis. 


\section{Ethics}

This article is original and contains unpublished material. The corresponding author confirms that all of the other authors have read and approved the manuscript and no ethical issues involved.

\section{References}

Abou-El-Hamd, E. M., Mohamed-Elamir, F. H., \& Moustafa, M. F. (2012). Euphorbia helioscopia: Chemical constituents and biological activities. International Journal of Phytopharmacology, 3(1), 78-90.

Agbafor, K. N., \& Nwachukwu, N. (2011). Phytochemical analysis and antioxidant property of leaf extracts of Vitex doniana and Mucuna pruriens. Biochemistry Research International, 2011.

Ahmed, N. (2009). Alloxan diabetes-induced oxidative stress and impairment of oxidative defense system in rat brain: Neuroprotective effects of cichorium intybus. Int J Diabetes \& Metabolism, 17, 105-109.

Ahmed, N., \& Zahra, N. (2011). Neurochemical correlates of alloxan diabetes: Glucose and related brain metabolism in the rat. Neurochemical research, 36(3), 494-505.

Al-Abachi, S. Z., Mustafa, L. A., Hassan, D. S. K., \& AlHadidi, A. A. (2012). Study of some biochemical changes in serum of patients with chronic renal failure. Iraqi National Journal of Chemistry, (46), 270-280.

Arora, R., \& Deshmukh, R. (2017). Embelin attenuates intracerebroventricular streptozotocin-induced behavioral, biochemical and neurochemical abnormalities in rats. Molecular neurobiology, 54(9), 6670-6680.

Bakırel, T., Bakırel, U., Keleş, O. Ü., Ülgen, S. G., \& Yardibi, H. (2008). In vivo assessment of antidiabetic and antioxidant activities of rosemary (Rosmarinus officinalis) in alloxan-diabetic rabbits. Journal of ethnopharmacology, 116(1), 64-73.

Bayati, S. \& Yazdanparast, R. (2011). Antioxidant and Free Radical Scavenging Potential of Yakuchinone B Derivatives in Reduction of Lipofuscin Formation Using H2O2-Treated Neuroblastoma Cells. Iranian Biomedical Journal, 15(4), 134-142.

Beltagy, A. M. (2019). Chemical composition and antibacterial activity of medicinally useful essential oil from the inflorescence of Euphorbia helioscopia 1. grown in egypt. International Journal of Pharmaceutical Sciences and Research, 10(8): 3660-3667.

Bertrand, A., \& Buret, J. (1982). A one-step determination of serum 5'-nucleotidase using a centrifugal analyzer. Clinica Chimica Acta, 119(3), 275-284.

Beutler, E. (1963). Improved method for the determination of blood glutathione. J. lab. clin. Med., 61, 882-888.
Bondan, E. F., Martins, M. D. F. M., \& Viani, F. C. (2013). Decreased astrocytic GFAP expression in streptozotocin-induced diabetes after gliotoxic lesion in the rat brainstem. Arquivos Brasileiros de Endocrinologia \& Metabologia, 57(6), 431-436.

Bukhari, S. S. I., Abbasi, M. H., \& Khan, M. K. A. (2015). Dose optimization of alloxan for diabetes in albino mice. Biologia (Pakistan), 61(2), 301-305.

Byersdorfer, C. A., Schweitzer, G. G., \& Unanue, E. R. (2005). Diabetes is predicted by the $\beta$ cell level of autoantigen. The Journal of Immunology, 175(7), 4347-4354.

Ceretta, L. B., Réus, G. Z., Abelaira, H. M., Ribeiro, K. F., Zappellini, G., Felisbino, F. F., ... \& Quevedo, J. (2012). Increased oxidative stress and imbalance in antioxidant enzymes in the brains of alloxan-induced diabetic rats. Experimental Diabetes Research, 2012.

Coleman, E., Judd, R., Hoe, L., Dennis, J., \& Posner, P. (2004). Effects of diabetes mellitus on astrocyte GFAP and glutamate transporters in the CNS. Glia, 48(2), 166-178.

Devi, S., \& Kumar, M. (2017). In-vivo Antidiabetic Activity of Methanolic Extract of Euphorbia hirta L. International Journal of Diabetes and Endocrinology, 2(3): 36-39.

Erukainure, O. L., Ebuehi, O. A., Adeboyejo, F. O., Aliyu, M., \& Elemo, G. N. (2014). Modulatory effect of fibre-enriched cake on alloxan-induced diabetic toxicity in rat brain tissues. Toxicology reports, 1, 445-449.

Gwarzo, M. Y., Nwachuku, V. A., \& Lateef, A. O. (2010). Prevention of alloxan induced diabetes mellitus in rats by vitamin A dietary supplementation. Asian Journal of animal sciences, 4(4), 190-196.

Ibrahim, D. S. (2017). Neuroprotective effect of Cucumis melo var. flexuosus leaf extract on the brains of rats with streptozotocin-induced diabetes. Metabolic brain disease, 32(1), 69-75.

Kalaivani, T., \& Mathew, L. (2010). Free radical scavenging activity from leaves of Acacia nilotica (L.) Wild. ex Delile, an Indian medicinal tree. Food and Chemical Toxicology, 48(1), 298-305.

Kung, C. P., \& Murphy, M. E. (2016). The role of the p53 tumor suppressor in metabolism and diabetes. The Journal of endocrinology, 231(2), R61.

Lensen, S. (2008). Mechanism of Alloxan and Streptozocin induced diabetes. Diabetologia, 51(2), 216-226.

Malviya, N., Jain, S., \& Malviya, S. A. P. N. A. (2010). Antidiabetic potential of medicinal plants. Acta pol pharm, 67(2), 113-118.

Mamum, A. A., Uddin, M. S., \& Wahid, F. (2016). Neurodefensive effect of Olea europaea L. Alloxaninduced cognitive dysfunction and brain tissue oxidative stress in mice: incredible natural nootropic. J Neurol Neurosci, 7, S3. 
Morton, N. M., Holmes, M. C., Fiévet, C., Staels, B., Tailleux, A., Mullins, J. J., \& Seckl, J. R. (2001). Improved lipid and lipoprotein profile, hepatic insulin sensitivity and glucose tolerance in $11 \beta$-hydroxysteroid dehydrogenase type 1 null mice. Journal of Biological Chemistry, 276(44), 41293-41300.

Nishikimi, M. (1975). Oxidation of ascorbic acid with superoxide anion generated by the xanthine-xanthine oxidase system. Biochemical and biophysical research communications, 63(2), 463-468.

Ogunnowo-Bada, E. O., Heeley, N., Brochard, L., \& Evans, M. L. (2014). Brain glucose sensing, glucokinase and neural control of metabolism and islet function. Diabetes, Obesity and Metabolism, 16(S1), 26-32.

Ohkawa, H., Ohishi, N., \& Yagi, K. (1979). Assay for lipid peroxides in animal tissues by thiobarbituric acid reaction. Analytical biochemistry, 95(2), 351-358.

Pandya, K., Clark, G. J., \& Lau-Cam, C. A. (2017). Investigation of the role of a supplementation with taurine on the effects of hypoglycemic-hypotensive therapy against diabetes-induced nephrotoxicity in rats. In Taurine 10 (pp. 371-400). Springer, Dordrecht.

Peschke, E., Ebelt, H., Brömme, H. J., \& Peschke, D. (2000). 'Classical'and 'new'diabetogenscomparison of their effects on isolated rat pancreatic islets in vitro. Cellular and Molecular Life Sciences CMLS, 57(1), 158-164.

Petchi, R. R., Parasuraman, S., \& Vijaya, C. (2013). Antidiabetic and antihyperlipidemic effects of an ethanolic extract of the whole plant of Tridax procumbens (Linn.) in streptozotocin-induced diabetic rats. Journal of basic and clinical pharmacy, 4(4), 88.

Quettier-Deleu, C., Gressier, B., Vasseur, J., Dine, T., Brunet, C., Luyckx, M., ... \& Trotin, F. (2000). Phenolic compounds and antioxidant activities of buckwheat (Fagopyrum esculentum Moench) hulls and flour. Journal of ethnopharmacology, 72(1-2), 35-42.

Reddy, Y. M., \& Uppala, P. K. (2014). Study of antioxidant activity of Euphorbia hirta Linn whole plant in mice. World Journal of Pharmacy and Pharmaceutical Sciences (WJPPS), 3(6), 1008-1022.

Rohlfing, C. L., Wiedmeyer, H. M., Little, R. R., England, J. D., Tennill, A., \& Goldstein, D. E. (2002). Defining the relationship between plasma glucose and HbA1c: analysis of glucose profiles and HbA1c in the Diabetes Control and Complications Trial. Diabetes care, 25(2), 275-278.

Saggu, S., Sakeran, M. I., Zidan, N., Tousson, E., Mohan, A., \& Rehman, H. (2014). Ameliorating effect of chicory (Chichorium intybus L.) fruit extract against 4-tert-octylphenol induced liver injury and oxidative stress in male rats. Food and chemical toxicology, 72, 138-146.
Sahu, U., Tiwari, S. P., \& Roy, A. (2015). Comprehensive notes on anti diabetic potential of medicinal plants and polyherbal formulation. UK Journal of Pharmaceutical and Biosciences, 3(3), 57-64.

Sakurai, K., \& Ogiso, T. (1991). Inhibitory effect of glutathione on the generation of hydroxyl radicals in the reaction system of glutathione-alloxan. Chemical and pharmaceutical bulletin, 39(3), 737-742.

Saleem, U., Mahmood, S., Ahmad, B., Saleem, M., \& Anjum, A. A. (2015). Estimation of genotoxic and mutagenic potential of latex and methanolic leaves extract of Euphorbia helioscopia by comet assay and Ames test. Asian Pac J Trop Dis 2015b, 5, S145-S150.

Schönfeld, P., \& Reiser, G. (2013). Why does brain metabolism not favor burning of fatty acids to provide energy?-Reflections on disadvantages of the use of free fatty acids as fuel for brain. Journal of Cerebral Blood Flow \& Metabolism, 33(10), 1493-1499.

Sherwin, R. S., \& Sacca, L. U. I. G. I. (1984). Effect of epinephrine on glucose metabolism in humans: contribution of the liver. American Journal of Physiology-Endocrinology And Metabolism, 247(2), E157-E165.

Sourianarayanane, A. (2018). Normal Hepatic Function and Physiology. In: Hepatic Critical Care, 2018:3-19.

Sy, G. Y., Cissé, A., Nongonierma, R. B., Sarr, M., Mbodj, N. A., \& Faye, B. (2005). Hypoglycaemic and antidiabetic activity of acetonic extract of Vernonia colorata leaves in normoglycaemic and alloxan-induced diabetic rats. Journal of ethnopharmacology, 98(1-2), 171-175.

Tang, H., Dong, X., Day, R. S., Hassan, M. M., \& Li, D. (2010). Antioxidant genes, diabetes and dietary antioxidants in association with risk of pancreatic cancer. Carcinogenesis, 31(4), 607-613.

Tousson, E. (2016). Histopathological alterations after a growth promoter boldenone injection in rabbits. Toxicology and industrial health, 32(2), 299-305.

Tousson, E., Ibrahim, W., Arafa, N., \& Akela, M. A. (2012). Monoamine concentrations changes in the PTU-induced hypothyroid rat brain and the ameliorating role of folic acid. Human \& experimental toxicology, 31(3), 282-289.

Uzair, M., Loothar, B. A., \& Choudhary, B. A. (2009). Biological screening of Euphorbia helioscopia L. Pakistan Journal of Pharmaceutical Sciences, 22(2).

Victor, N. O., Obiora, A., Egba, S. I. \& Ikechukwu, U. R. (2017). Modulation of Blood Glucose Concentration, Lipid Profile and Haematological Parameters in Alloxan Induced Diabetic Rats Using Methanol Extract of Nauclea latifolia Root Bark. Asian Journal of Biological Sciences, 10(1): 1-8. 
Doha Mohammad Beltagy et al. / OnLine Journal of Biological Sciences 2020, 20 (3): 144.156 DOI: 10.3844/ojbsci.2020.144.156

Wang, Z. Y., Liu, H. P., Zhang, Y. C., Guo, L. Q., Li, Z. X., \& Shi, X. F. (2012). Anticancer potential of Euphorbia helioscopia L extracts against human cancer cells. The Anatomical Record: Advances in Integrative Anatomy and Evolutionary Biology, 295(2), 223-233.
Zhou, Y., \& Danbolt, N. C. (2014). Glutamate as a neurotransmitter in the healthy brain. Journal of neural transmission, 121(8), 799-817. 